九州大学学術情報リポジトリ

Kyushu University Institutional Repository

\title{
Two-Dimensional Analysis of Nitrate Nitrogen Movement under Drip Irrigation
}

Nomura, Koichi

Laboratory of Irrigation and Water Management, Division of Bioproduction Environmental Sciences, Department of Agro-environmental Sciences, Graduate School of Bioresource and Bioenvironmental Science, Kyushu University

\section{Yuge, Kozue}

九州大学大学院農学研究院環境農学部門生産環境科学講座灌䦾利水学研究室

Shinogi, Yoshiyuki

九州大学大学院農学研究院環境農学部門生産環境科学講座灌㳻利水学研究室

https://doi.org/10.5109/20336

出版情報 : 九州大学大学院農学研究院紀要. 56 (2), pp. 389-393，2011-09. 九州大学大学院農学研究院 バージョン：

権利関係 : 


\title{
Two-Dimensional Analysis of Nitrate Nitrogen Movement under Drip Irrigation
}

\section{Koichi NOMURA ${ }^{1}$, Kozue YUGE* and Yoshiyuki SHINOGI}

\author{
Laboratory of Irrigation and Water Management, Division of Bioproduction Environmental Sciences, \\ Department of Agro-environmental Sciences, Faculty of Agriculture, \\ Kyushu University, Fukuoka 812-8581, Japan \\ (Received April 27, 2011 and accepted May 9, 2011)
}

\begin{abstract}
The objective of this paper was to clarify the temporal and spatial two-dimensional variations of volumetric water content and $\mathrm{NO}_{3}-\mathrm{N}$ concentration in soil under drip irrigation. A numerical model was used for estimating temporal and spatial movements of water and $\mathrm{NO}_{3}-\mathrm{N}$ in soil. Laboratory experiments were conducted to estimate the physical properties such as soil water retentivity and conductivity. A field observation was conducted to evaluate the model accuracy. The temporal and spatial changes of volumetric water content and $\mathrm{NO}_{3}-\mathrm{N}$ concentration in soil were measured in a $1 \mathrm{~m} \times 1 \mathrm{~m} \times 1 \mathrm{~m}$ lysimeter where $\mathrm{NH}_{4} \mathrm{NO}_{3}$ solution was supplied in a row. The results of simulation calculated by the model agreed well with observed data. By using the model, temporal and spatial variations of soil water content and $\mathrm{NO}_{3}-\mathrm{N}$ concentration were calculated. The results described simultaneous movements of water and $\mathrm{NO}_{3}-\mathrm{N}$ spreading in a soil profile. The numerical model introduced here can be effective to estimate variations of water and $\mathrm{NO}_{3}-\mathrm{N}$ in soil
\end{abstract}

\section{INTRODUCTION}

Drip irrigation is a method that saves water and fertilizer by allowing water to drip slowly onto the soil surface or directly to the root zone. In this irrigation system, fertigation, the application of dissolved fertilizers with water, has been used. A variety of chemicals are dissolved in the water. $\mathrm{NO}_{3}-\mathrm{N}$, which is one of the common chemicals of fertilizers, can easily leach to the ground water table because it is eluvial at moderate $\mathrm{pH}$ (Jury and Horton, 2006). $\mathrm{NO}_{3}-\mathrm{N}$ in drinking water can cause low oxygen levels in the blood of infants, which is a potentially fatal condition (Bernard et al., 1997). Clarifying simultaneous transport of water and $\mathrm{NO}_{3}-\mathrm{N}$ in soil is important and the proposition of effective irrigation methods is necessary to prevent $\mathrm{NO}_{3}-\mathrm{N}$ from reaching the ground water table.

Numerous studies have been conducted to estimate the movements of $\mathrm{NO}_{3}-\mathrm{N}$ in soil. Nakamura et al. (2004) studied temporal and vertical variations of $\mathrm{NO}_{3}-\mathrm{N}$ and $\mathrm{NH}_{4}-\mathrm{N}$ concentrations including nitrification in root zone. Some models describing temporal and spatial multidimensional movement of solute, such as HYDRUS (2D/3D) (Šimůnek et al., 2008), have been developed. However, there have been few papers published on the investigation of two-dimensional changes of water and $\mathrm{NO}_{3}-\mathrm{N}$ in soil under drip irrigation.

The goal of the current study was to clarify temporal and spatial two-dimensional variations of volumetric water content and $\mathrm{NO}_{3}-\mathrm{N}$ concentration in soil under drip irrigation by using a combination of experiments and modeling.

\footnotetext{
Laboratory of Irrigation and Water Management, Division of Bioproduction Environmental Sciences, Department of Agroenvironmental Sciences, Graduate School of Bioresource and Bioenvironmental Science, Kyushu University

* Corresponding author (E-mail: yuge@bpes.kyushu-u.ac.jp)
}

\section{METHODLOGY}

\section{Governing equation of water and $\mathrm{NO}_{3}-\mathrm{N}$ transfer in soil}

A numerical model describing water flow and $\mathrm{NO}_{3}-\mathrm{N}$ transport in soil was used to predict the temporal and spatial variations of $\mathrm{NO}_{3}-\mathrm{N}$ concentration with water flow.

Two-dimensional water movement in isotropic soil can be computed by solving Richards' equation as follows:

$$
C_{w} \frac{\partial \phi_{m}}{\partial t}=\frac{\partial}{\partial x}\left(k_{w} \frac{\partial \phi_{m}}{\partial x}\right)+\frac{\partial}{\partial z}\left(k_{w} \frac{\partial \phi_{m}}{\partial z}\right)+\frac{\partial k_{w}}{\partial z}
$$

where $\phi_{m}$ is the pressure head $\left(\mathrm{cmH}_{2} \mathrm{O}\right), C_{w}$ is the water capacity function $\left(\mathrm{cm}^{-1}\right), k_{w}$ is the unsaturated hydraulic conductivity $\left(\mathrm{cm} \mathrm{s}^{-1}\right), t$ is the time $(\mathrm{s}), x$ is the horizontal coordinate $(\mathrm{cm})$, and $z$ is the vertical coordinate $(\mathrm{cm})$.

The relationship between the volumetric water content, $\theta\left(\mathrm{cm}^{3} \mathrm{~cm}^{-3}\right)$ and $\phi_{m}$ is represented by the following equation (van-Genuchten, 1980):

$$
\theta\left(\phi_{m}\right)=\theta_{r}+\left(\theta_{s}-\theta_{r}\right)\left[1+\left(-\alpha \phi_{m}\right)^{n}\right]^{\frac{1-n}{n}}
$$

where $\theta_{s}$ is the saturated volumetric water content $\left(\mathrm{cm}^{3} \mathrm{~cm}^{-3}\right), \theta_{r}$ is the residual volumetric water content $\left(\mathrm{cm}^{3} \mathrm{~cm}^{-3}\right)$, and $\alpha$ and $n$ are parameters.

The unsaturated hydraulic conductivity is defined as follows (van-Genuchten, 1980):

$$
k_{w}\left(\phi_{m}\right)=k_{w s}\left[\frac{1}{1+\left(-\alpha \phi_{m}\right)^{n}}\right]^{\frac{n-1}{2 n}}\left[1-\left\{1-\frac{1}{1+\left(-\alpha \phi_{m}\right)^{n}}\right\}^{\frac{n-1}{n}}\right]^{2}
$$

where $k_{w s}$ is the saturated hydraulic conductivity $\left(\mathrm{cm} \mathrm{s}^{-1}\right)$.

Two-dimensional soluble $\mathrm{NO}_{3}-\mathrm{N}$ movement in isotropic soil can be computed by solving convection-diffusion equation described below: 


$$
\begin{aligned}
\frac{\partial}{\partial t}(\theta C) & =\frac{\partial}{\partial x}\left(\theta D_{c x} \frac{\partial C}{\partial x}\right)+\frac{\partial}{\partial z}\left(\theta D_{c z} \frac{\partial C}{\partial z}\right) \\
& -\frac{\partial}{\partial x}\left(q_{w x} C\right)-\frac{\partial}{\partial z}\left(q_{w z} C\right)
\end{aligned}
$$

where $C$ is the soluble $\mathrm{NO}_{3}-\mathrm{N}$ concentration (mgN $\left.\mathrm{cm}^{-3}\right), D_{c}$ is the dispersion coefficient $\left(\mathrm{cm}^{2} \mathrm{~s}^{-1}\right)$, and $q_{w}$ is the water flux $\left(\mathrm{cm}^{3} \mathrm{~s}^{-1}\right)$. Sorption of $\mathrm{NO}_{3}-\mathrm{N}$ was negligible. The dispersion coefficient of soluble substance can be estimated as follows:

$$
\theta D_{c}=D_{0} a \exp (b \theta)+\lambda\left|q_{w}\right|
$$

where $D_{0}$ is the molecular diffusion coefficient in free water $\left(\mathrm{cm}^{2} \mathrm{~s}^{-1}\right), \lambda$ is the longitudinal dispersivity $(\mathrm{cm})$, and $a$ and $b$ are the parameters.

\section{Initial and Boundary Conditions}

For the simulation of the field experiment described in the following section, initial conditions of volumetric water content and soluble $\mathrm{NO}_{3}-\mathrm{N}$ were obtained by linear interpolation of measured profile values just prior to irrigation. The boundary condition of water movement at soil surface was given by specified irrigation rates $q_{w \text { irri, }}$ and a constant evaporation rate $q_{w \text { eva }}$. The boundary condition of $\mathrm{NO}_{3}-\mathrm{N}$ at soil surface was given by the $\mathrm{NO}_{3}-\mathrm{N}$ flux $q_{\text {cirri }}$ with irrigation. Boundary conditions at the walls and the bottom were set as fluxes equal to zero in both water and $\mathrm{NO}_{3}-\mathrm{N}$ simulation.

\section{Model Description}

To solve the governing equations shown in eqs.(1) and (4), the finite-differential method was used. The numerical model for estimating water and $\mathrm{NO}_{3}-\mathrm{N}$ movements are shown in Fig. 1 with the boundary conditions. The $1 \mathrm{~m} \times 1 \mathrm{~m}$ domain was divided into $60 \times 60$ grids. The time step was 0.05 second during irrigation and 1 second after the irrigation.

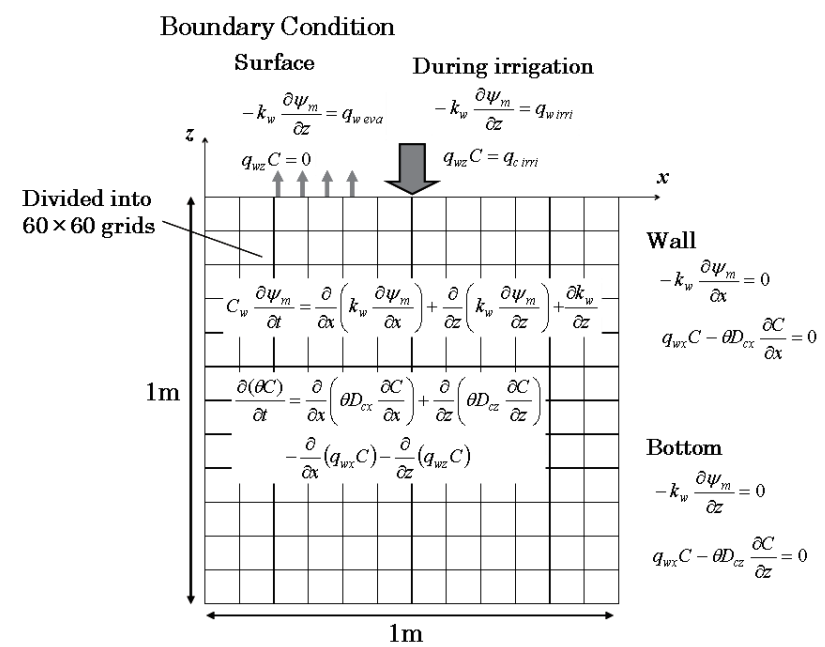

Fig. 1. Numerical model for predicting the movement of water and $\mathrm{NO}_{3}-\mathrm{N}$ in soil.

\section{EXPERIMENTS}

\section{Laboratory Experiments}

Laboratory experiments were conducted to determine some soil physical properties, including the soil water retentivity and conductivity, to apply the numerical model shown in Fig. 1. Granite soil was used in the experiments; this was also used in the field observation

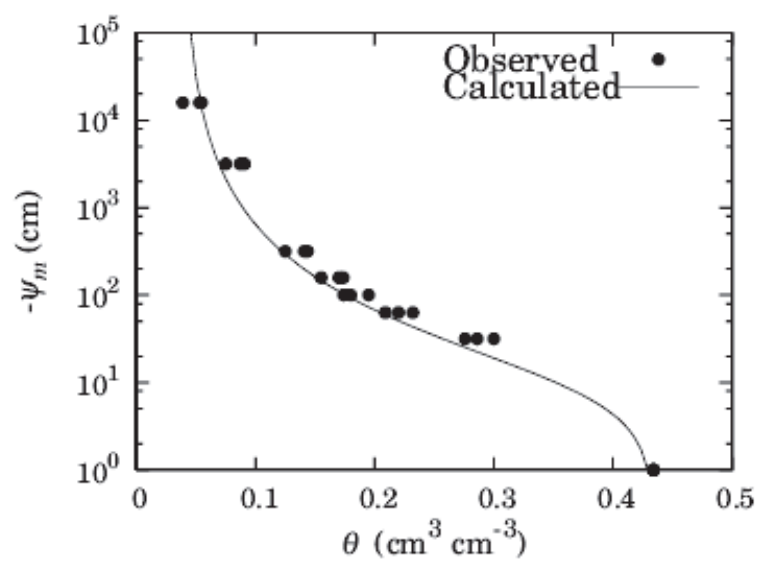

Fig. 2. Water retention curve.

Table 1. Parameters for van-Genuchten equation

\begin{tabular}{ccccc}
\hline$\theta_{s}\left(\mathrm{~cm}^{3} \mathrm{~cm}^{-3}\right)$ & $\theta_{r}\left(\mathrm{~cm}^{3} \mathrm{~cm}^{-3}\right)$ & $\alpha$ & $n$ & $k_{\text {ws }\left(\mathrm{cms}^{-1}\right)}$ \\
\hline 0.434 & 0.039 & 0.110 & 1.438 & $1.72 \times 10^{-3}$ \\
\hline
\end{tabular}

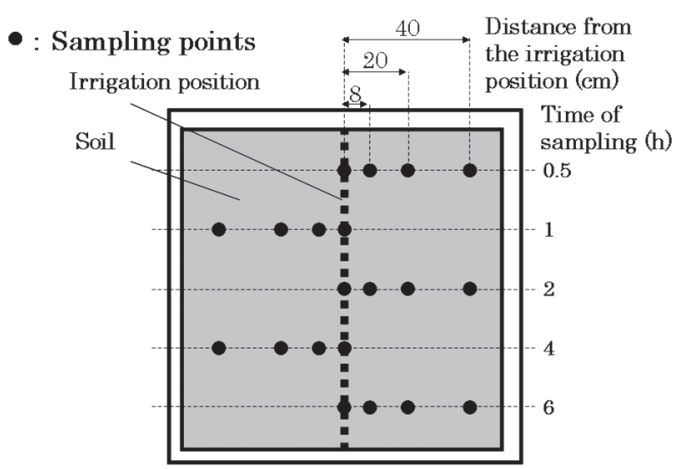

Fig. 3. Plan view of the lysimeter.

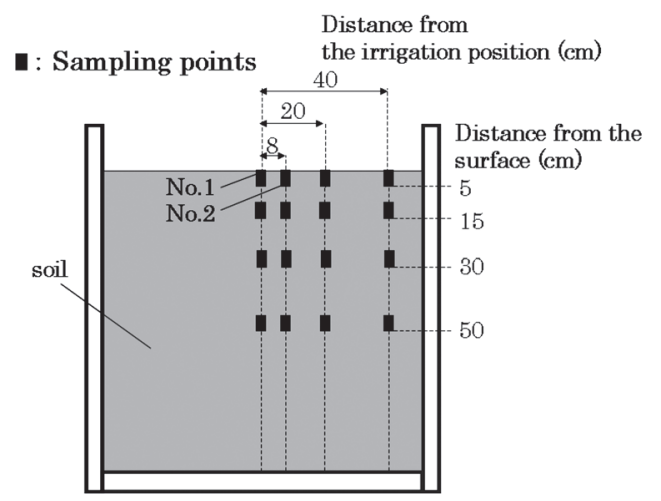

Fig. 4. Soil sampling profile of the lysimeter. 
described below. The saturated water conductivity, $k_{w s}$, in eq.(3), was obtained by the falling head method. The water retention curve was obtained by the hanging water column method and the centrifuge method. The residual volumetric water content, $\theta_{r}$ and the parameters, $\alpha$ and $n$ in eqs.(2) and (3), were determined by the least squares method for the data. The retention curve calculated by eq.(2) and observed values are represented in Fig. 2. The values used in eqs.(2) and (3) are represented in Table 1.

\section{Field Observation}

The accuracy of the numerical model for estimating water flow and $\mathrm{NO}_{3}-\mathrm{N}$ transport in soil was verified by a field observation using $1 \mathrm{~m} \times 1 \mathrm{~m} \times 1 \mathrm{~m}$ lysimeters. The lysimeters were filled with the granite soil. To simulate a condition of drip irrigation with dissolved fertilizer, $1 \mathrm{~L}$ of $\mathrm{NH}_{4} \mathrm{NO}_{3}$ solution with a concentration of $500 \mathrm{mgN} \mathrm{L}^{-1}$ was supplied at the center row of the lysimeter (Fig. 3). Irrigation intensity was $6.2 \mathrm{~mm} \mathrm{~h}^{-1}$. Soil samplings were conducted at the points shown in Fig. 4 to investigate the volumetric water content and the $\mathrm{NO}_{3}-\mathrm{N}$ concentration at $0,0.5,1,2,4$, and 6 hours after the irrigation.

\section{RESULTS AND DISCUSSION}

\section{Model Validation}

Simulated and observed values of volumetric water content and $\mathrm{NO}_{3}-\mathrm{N}$ concentration in soil are shown in Figs. 5 and 6, respectively. The sampling points of Figs. 5 and 6 are shown in Fig. 4. The simulated values have relatively good agreement with the observed values. The results indicate that the model is valid. Differences between the simulated and the observed values might be caused by non-uniformity of soil physical characteristics and initial distribution of water and $\mathrm{NO}_{3}-\mathrm{N}$.

\section{Spatial distributions of water and $\mathrm{NO}_{3}-\mathrm{N}$ concen- tration in soil}

The temporal and spatial variations of the soil water content and $\mathrm{NO}_{3}-\mathrm{N}$ concentration simulated by the use of the numerical model are shown in Figs. 7 and 8. The assumed conditions in this simulation are represented in Table 2. The soil properties in the simulation are the same as those in the laboratory experiments above. As shown in Figs. 7 and 8, $\mathrm{NO}_{3}-\mathrm{N}$ is transferred with soil water by convection. The area of $\mathrm{NO}_{3}-\mathrm{N}$ distribution is larger than the area of water distribution because the dispersivity $\lambda$ used in the simulation is relatively large (Jury and Horton, 2004) and diffusion also occurs even if there is no water flow.

Table 2. Initial and boundary conditions

\begin{tabular}{ll}
\hline Initial volumetric water content $\left(\mathrm{cm}^{3} \mathrm{~cm}^{-3}\right)$ & 0.089 \\
Initial $\mathrm{NO}_{3}-\mathrm{N}$ concentration $(\mathrm{mgN} \mathrm{cm}$ & 0 \\
Water flux of irrigation $\left(\mathrm{cm} \mathrm{s}^{-1}\right)$ & 0.00139 \\
$\mathrm{NO}_{3}-\mathrm{N}$ concentration of irrigation water $\left.(\mathrm{mgN} \mathrm{cm})^{-3}\right)$ & 0.25 \\
Evaporation rate $\left(\mathrm{cm} \mathrm{s}^{-1}\right)$ & 0 \\
Dispersivity $(\mathrm{cm})$ & 5 \\
\hline
\end{tabular}

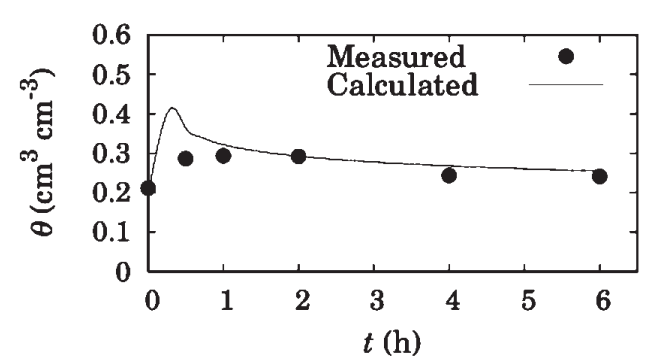

(a) No.1

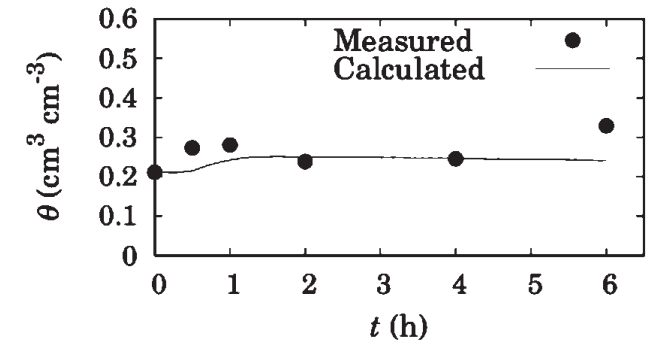

(b) No.2

Fig. 5. Calculated and measured values of volumetric water content $\theta$ in soil.

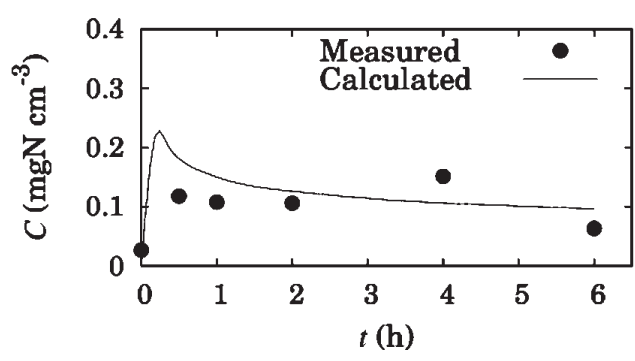

(a) No.1

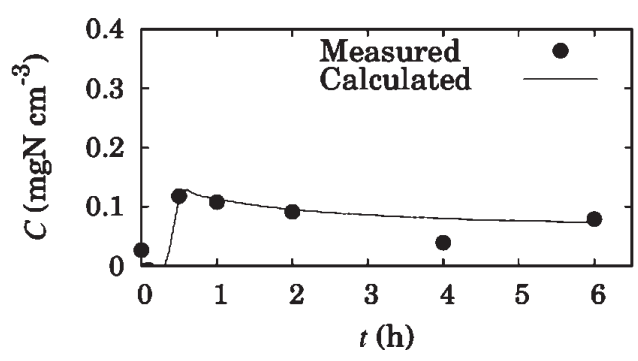

(b) No.2

Fig. 6. Calculated and measured values of $\mathrm{NO}_{3}-\mathrm{N}$ concentration $C$ in soil. 


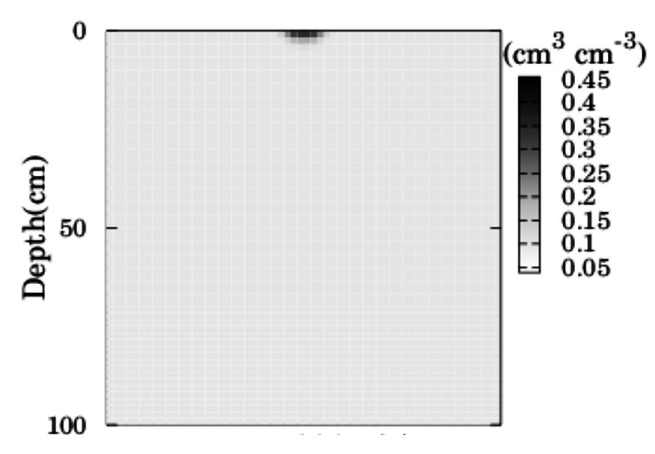

(a) $t=600 \mathrm{~s}$

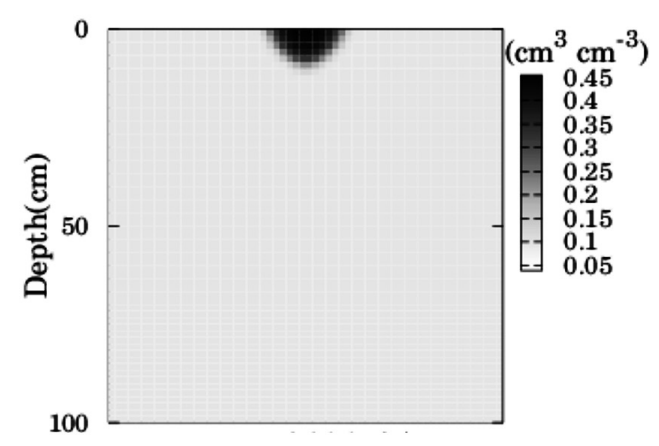

(b) $t=3600 \mathrm{~s}$

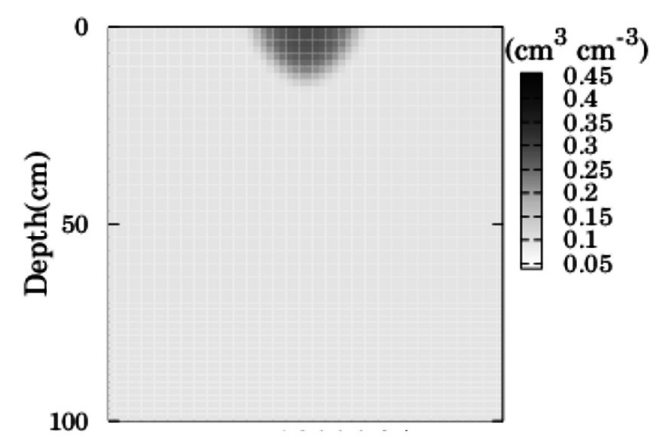

(c) $t=18000 \mathrm{~s}$

Fig. 7. Temporal and spatial variations of volumetric water content in soil.

\section{CONCLUSIONS}

To clarify temporal and spatial two-dimensional variations of volumetric water content and $\mathrm{NO}_{3}-\mathrm{N}$ concentration in soil under drip irrigation, a numerical model for estimating temporal and spatial movements of water and $\mathrm{NO}_{3}-\mathrm{N}$ in soil was used. Laboratory experiments were conducted to estimate the physical properties including soil water retentivity and conductivity. A field observation was conducted to verify the model accuracy. The temporal and spatial changes of volumetric water content and $\mathrm{NO}_{3}-\mathrm{N}$ concentration in soil were measured in a $1 \mathrm{~m} \times 1 \mathrm{~m} \times 1 \mathrm{~m}$ lysimeter where $\mathrm{NH}_{4} \mathrm{NO}_{3}$ solution was supplied in a row. The results of simulation calculated by the model had good agreement with observed data. By

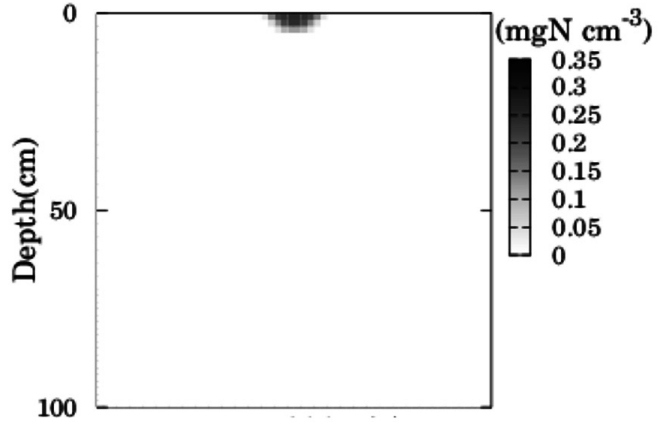

(a) $t=600 \mathrm{~s}$

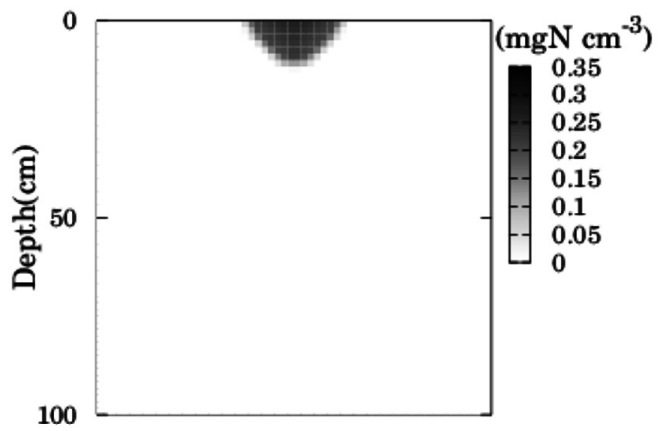

(b) $t=3600 \mathrm{~s}$

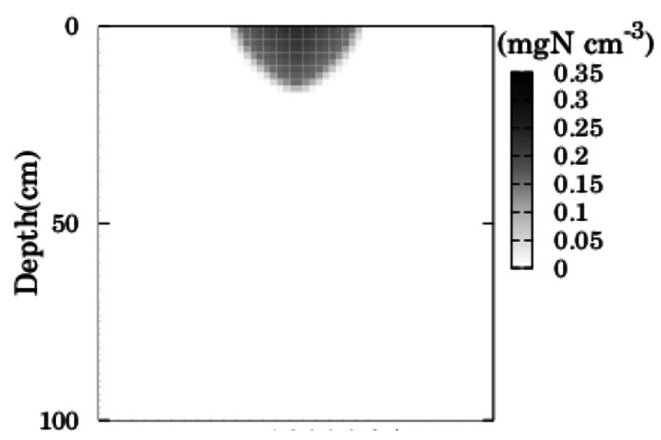

(c) $t=18000 \mathrm{~s}$

Fig. 8. Temporal and spatial variations of $\mathrm{NO}_{3}-\mathrm{N}$ concentration in soil.

using the model, temporal and spatial variations of soil water content and $\mathrm{NO}_{3}-\mathrm{N}$ concentration were calculated. The results described the simultaneous movement of water and $\mathrm{NO}_{3}-\mathrm{N}$ spreading in a soil profile. The numerical model introduced here can be effective to estimate the variations of water and $\mathrm{NO}_{3}-\mathrm{N}$ in soil. This model can contribute to the prevention of groundwater contamination by $\mathrm{NO}_{3}-\mathrm{N}$, and to plan proper fertilizer application in drip irrigation fields.

\section{REFERENCES}

Jury, W. A. and R. Horton 2004 SOIL PHYSICS $6^{\text {th }}$ Edition. Transl. by N. Toride., John Wiley \& Sons, Inc

Nakamura, K., T. Harter, Y. Hirono, H. Horino and T. Mitsuno 
2004 Assessment of root zone nitrogen leaching as affected by irrigation and nutrient management practices. Vadose Zone J., 3: 1353-1366

Nolan, B. T., B. C. Ruddy, K. J. Hitt and D. R. Helsel 1997 Risk of nitrate in groundwaters of the United States-A National Perspective. Envirn. Sci. Technol., 31: 2229-2236

Šimůnek, J., M. Th. van Genuchten and M. Šejna 2008 Modeling subsurface water flow and solute transport with HYDRUS and related numerical software packages. Proceedings of the International Workshop on Numerical Modelling of Hydrodynamics for Water Resources-Numerical Modelling of Hydrodynamics for Water Resources, 95-114

Van-Genuchten, M. Th. 1980 A closed-form equation for predicting the hydraulic conductivity of unsaturated soils. Soil Sci. Soc. Am. J., 44: 892-898 